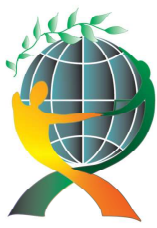

\author{
(online) $=$ ISSN $2285-3642$ \\ ISSN-L = $2285-3642$ \\ Journal of Economic Development, Environment and People \\ Volume 5, Issue 1, 2016
}

URL: http://jedep.spiruharet.ro

e-mail: office jedep@spiruharet.ro

\title{
Active Social Programs and Their Strategic Advantages in Labour Market Development
}

\author{
Evgeniy Stoyanov ${ }^{1}$ \\ ${ }^{1}$ University of Agribusiness and Rural Development - Plovdiv, Bulgaria
}

\begin{abstract}
The active programs and measures on the labour market are the subject of increasing interest and comment not only because of the expectations for tangible effects, but also because of the relatively significant financial resources necessary for their implementation. The paper discussed the active social programs and their strategic advantages in labour market development considering the methodology of their development and emphasising the role of human resources and innovative technologies.
\end{abstract}

Keywords: labour market, social policies, active programs, social programming.

JEL Codes: $E 2, A 13, L 31, M 14$

\section{Introduction}

The so called active programs and measures on the labour market take a special place among the macroeconomic policies and resources (Terziev, 2015b). They are subject to an increasing interest and comment not only because of the expectations for tangible effects, but also due to the relatively significant financial resources needed for their implementation. In the practical assessment of active programs and measures, researchers often face a number of problems arising from their multipurpose and multifaceted nature: lack of a unified and well-established evaluation methodology; measurement errors and lack of adequate statistical information; objective impossibility to track persons and to determine the benefits of participation in such programs. More than a hundred studies have been carried out on various active programs in the world and they have given ambiguous and often contradictory results as regards the effectiveness of these programs. The results are strongly influenced by the peculiarities of the country, the term and the manner of the program implementation (Terziev \& Arabska, 2015a).

The starting point for the evaluation of active programs and measures is the clarification of the goals, the tasks and the expected outcomes of the program. Active programs have multiple effects on the labour market. Appeared as a means of reducing unemployment, today they are associated with very broad anticipated effects of their application. Generally, active programs can be regarded as a tool for supporting the effective functioning of the labour market (Terziev \& Arabska, 2015b). They provide assistance to removing the obstacles and the problems for the functioning of the market economy.

\footnotetext{
${ }^{1}$ E-mail address: evg_stojanov@abv.bg
} 


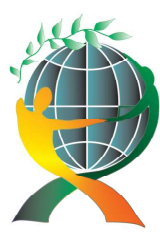

\author{
(online) $=$ ISSN $2285-3642$ \\ ISSN-L = $2285-3642$ \\ Journal of Economic Development, Environment and People \\ Volume 5, Issue 1, 2016 \\ URL: http://jedep.spiruharet.ro \\ e-mail: office jedep@spiruharet.ro
}

\title{
2. Contemporary problems in social management
}

Active programs are a means of enhancing the competitiveness of the workforce, mobilizing the labour resources and increasing the economic activity of the population (Terziev, Dimitrova \& Arabska, 2015a). In the absence of credit funds, microcredit schemes become real and often the only means for the development of small and medium-sized business in the country. Active policy performs a very important socio-distribution function, especially in the presence of disadvantaged groups in the labour market. For the latter, the participation in active programs is often the only chance for employment, thus preventing them from falling into extreme poverty and social deprivation (isolation). Last but not least, the proper definition of the objectives and the expected results from active programs and measures and their appropriate disclosure in the public space determine the extent, the trust and the support for the socioeconomic reforms in the country.

In the conditions of building an information society, new theoretical approaches originate, a new model of active, dynamically self-developing social programs is formed - programs that can be actively selfimproved and adapted to the dynamically changing social life conditions (Terziev \& Dimitrova, 2015). In the new conditions, there is also an increasing actual need for targeting the social programs towards a solution of the problems of intellectual and educational development, but at the same time the characteristics of health and physical development do not lose their social significance. Today, public health is a real indicator of the country's wealth, a reflection of the quality of life and the level of development of human resources. The health state is directly related to the income per capita and the maintenance of the health care system.

In summary, we can say that, in the conditions of a market economy, the contemporary social programs can occur in many forms, which in turn have specific principles, methods, technologies for identifying and reaching social goals, ways and means for the realization of human resources development. The general trend in the development and implementation of social programs for human resources development lies in the fact that their main target orientation is related to solving the problem of health and physical development of the population, the intellectual and educational development of human resources.

The application of social programs in a modern market system of production requires not only deep knowledge and understanding of its nature and essence, but also creative skills for using the specific forms of the method of social management, elaborating detailed technical procedures for the drawing up of social programs and their implementation in accordance with the principles of the systematic social management (Terziev, 2015c).

Objectively, the population prefers to participate in active social programs synthesizing active projects as a complex of flow projects at the heart of which lie social processes directed towards human development (Terziev, 2015a). The social processes based on active programming and projecting have an unbalanced, dynamic nature and this is why they are in the forefront of active social programs.

In the new conditions, the development of programs requires an active research and innovative work for setting its self-development in the mechanism of its implementation. The adequacy of the programtargeted social management (Stoyanov, 2015) in an unstable and constantly changing way of life is 


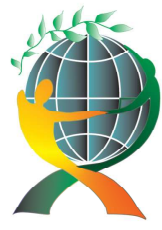

\author{
(online) $=$ ISSN $2285-3642$ \\ ISSN-L = $2285-3642$ \\ Journal of Economic Development, Environment and People \\ Volume 5, Issue 1, 2016 \\ URL: $\underline{\text { http://jedep.spiruharet.ro }}$ \\ e-mail: office jedep@spiruharet.ro
}

manifested in its orientation towards an active examination of the results from the social program implementation (social evaluation of the implementation results), attracting large groups of the population for its development. Active social programs are a system of social projects with a direct and a reverse link of social interaction, which determines the opportunities for adaptation of the program components to its changing demands. Moreover, in connection with the implementation of the social program there can be a change in its social objectives, implementation deadlines, partly in the participants and there can be a transformation of the attracted social resource.

\title{
3. Development of active social programs: strategic advantages and challenges
}

Nowadays, in their essence, the active social programs reflect the transition from a traditional to an innovative model of social development. It is this transition that determines the complex utilization of social programs within the innovative creativity, the partner relations of the participants in the program, the delegation of auxiliary functions to lower structures, but also the wide participation of the population in the implementation of the programs.

The methodology of the development of an active social program requires focusing on the following theoretical components (Terziev, 2015b):

- Establishment of the social problem. Apprehending a clearer understanding of the problem and a more reasonable control over certain key processes, we can turn the crisis into an opportunity, thus helping people not just to survive, but also to reach the tops of the waves of change and gain a new sense of mastery over their own destinies.

- Determining the social objective of the program is the starting point for programming the process of the human resources development. The external social environment provides an objective characteristic of the surrounding conditions, the parameters and the structure of external objects, interacting with the subject in one degree or another.

- The design of the planned trajectory for human resource development takes place within and by taking into account the comprehensive set of federal and regional programs, approved for implementation in line with predetermined social criteria.

The design of the trajectory of human resources development is related to the solving of the following objective tasks: first, determining the initial coordinates of the process of the human resources development; second, description of the conditions and the parameters of its extreme states (the final coordinates of the movement trajectory); third, setting the criteria for qualitative and quantitative indicators of the human resources development.

It should be noted that the most important goal of modern social programs is determined by the proactive level of knowledge, foresight and achievement of socially significant consequences from the future within the shaping of the general education process. Reaching a goal can serve as a criterion during the implementation of the model for proactive education as a basis of social construction of anticipatory human development. In its essence, this social construction is a synthesis result of the implementation of complex active social programs in society. Proactive educational development of human resources at society level reflects the transition of individuals from one socio-professional layer to another, accompanied by the development of the capabilities and the needs of individuals through the utilization of 


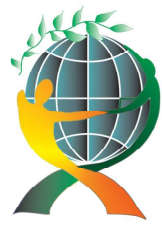

\author{
(online) $=$ ISSN $2285-3642$ \\ ISSN-L = 2285 - 3642 \\ Journal of Economic Development, Environment and People \\ Volume 5, Issue 1, 2016 \\ URL: http://jedep.spiruharet.ro \\ e-mail: office jedep@spiruharet.ro
}

one or another set of universal cultural items - language, symbols, customs, traditions, social norms, general and specialized knowledge - translational with the education and self-learning system of the society and providing an opportunity for continuous objectification of personal skills, habits, experience in the system of social professional action (Terziev, 2015b).

The central axis in the search for optimal forms of social construction is a dynamically developing system of education and a new type of dynamically developing intelligence, a new personality, corresponding to it. This position can be argued with the fact that the educational system is a social industry which prepares specialists in one or another type of thinking, this is a spiritual targeted development of this or that type of personality, i.e. it is essentially a system of expanded reproduction of the spiritual culture of society members. The society transforms and evolves rapidly and the system of educational institutions, pedagogical practice is an obstacle to this process. Educational institutions of a different rank record a quantitative growth of graduate specialists, without taking into consideration the conformity of their qualities with the growing needs of the current social development. This contradiction can only be overcome by providing conditions for competition of the structural elements of the education system, which is oriented in a targeted way to the development of the literacy of different population layers. Namely the educational development of human resources, defining the totality of the acquired systematic knowledge, skills and professional habits, but also the acquired skills for further learning and analysis of knowledge, the exchange and the use of information in the course of professional activity are the most important factors and social objectives of the entire social policy (Terziev, Dimitrova \& Arabska, 2015b).

An active social program also features dynamic adjustment regulation through the including of feedback upon its implementation. The functions of the adjustment regulator are a kind of solution to the task of optimization of its components as a result of the changes in the conditions of the activity of the population - bringing under control the disturbing external social impulses arising upon the social program implementation.

The adjustment regulator of the program consists of three interrelated parts: a system for social research, an organic system for planning and an organic regulatory system. The system for social research is executed by methods for studying the social interests of the population. As a result, the social studies reveal the needs and the population's preferences for certain social benefits: housing, health promotion, sport and cultural needs, advanced training and retraining. Social planning is implemented for the purpose of addressing a social problem caused by the mismatch between the social program components and the changed requirements.

Social regulation is a process of creating conditions for active realization of the social program. The successful implementation of the social regulation contributes to the unification of the participants in the program, the approximation of their interests and the interests of the population being targeted by the program.

The specified components are completely identical in structure and consist of the following interrelated parts: forecasting (anticipatory reflection of reality); planning of the social changes in the components of the system; simulation model for the formation of the program implementation process; 


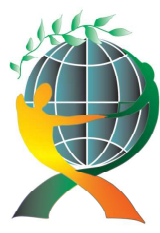

\author{
(online) $=$ ISSN $2285-3642$ \\ ISSN-L = $2285-3642$ \\ Journal of Economic Development, Environment and People \\ Volume 5, Issue 1, 2016
}

URL: http://jedep.spiruharet.ro

e-mail: office jedep@spiruharet.ro

immediate internal adapter of the program management system; external adapter of the program management system; internal adapter of the program management system.

The principle of anticipatory reflection of reality expresses the possibility of adaptation of society to changing environmental conditions and the actual possibility of existence, the ability of realization of the current and future reality. The anticipatory reflection of social reality is one of the forms of reflecting the future social development, which is a historical foundation for the emergence of all higher forms of the forecasting of future events and above all the emergence of conditioned reflex. In the social program the principle of anticipatory reflection of reality is expressed in the considering of the determination of the future features of the project impact: social forecasting, social prognosis, social design, social programming, social planning, social construction, social engineering. Based on the principle of anticipatory reflection of the social reality, "in this dimension one can formulate the principle of anticipatory reflection of the social reality as a fundamental principle of social design" (Terziev \& Dimitrova, 2015).

In the new conditions, the theoretical paradigm of social programs requires a synthesis with the theory of active systems, which must objectively lead to the provision of conditions and motivational activity among the participants of the targeted social program. Namely, the activity feature of a system element mostly corresponds to the model of an active targeted social program, for the implementation of which individual actors were attracted: the population, the state and the public social institutions.

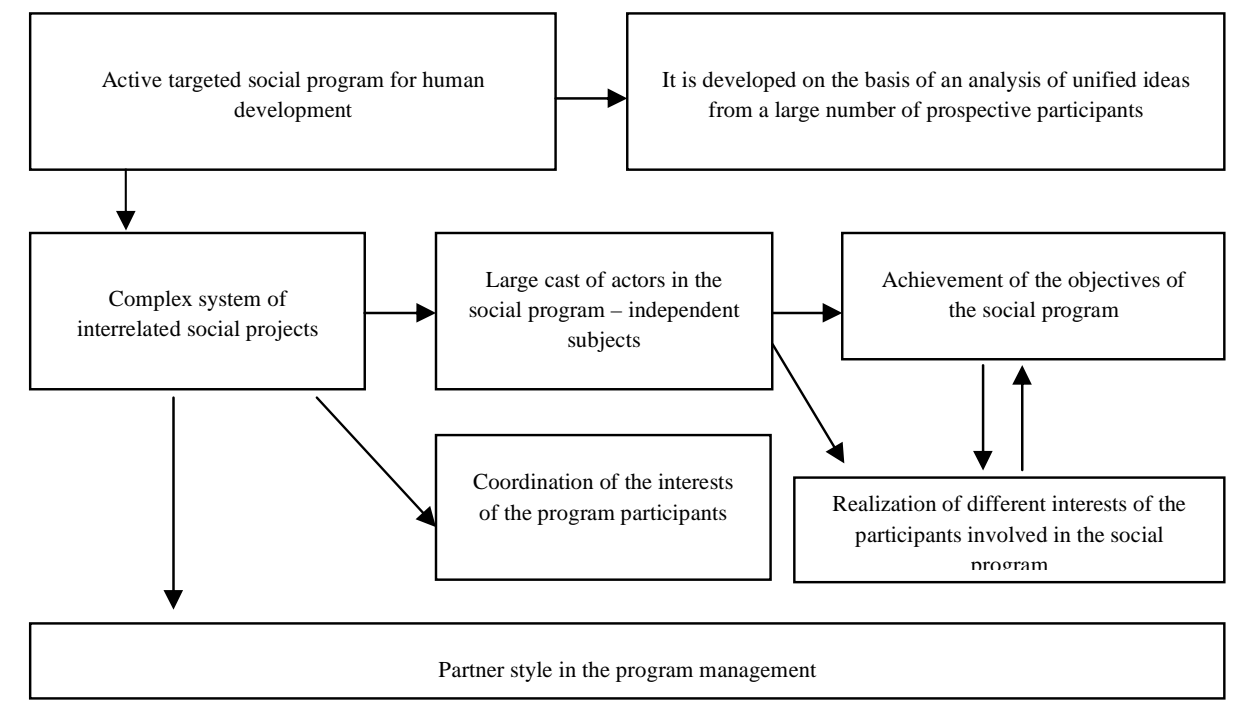

Fig. 1. Characteristics of an active social program of human development (Terziev \& Arabska, 2015c)

The theory of active systems is transformed into a part of the theory of social program management determining the social adaptability of social programs, the use of more participants in the program, the realization of their activity. Namely, the property of the system element activity mostly corresponds to the active model of the social program. Activity is manifested in the partners' autonomy and the interest of the 


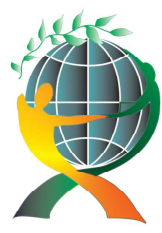

\author{
(online) $=$ ISSN $2285-3642$ \\ ISSN-L = $2285-3642$ \\ Journal of Economic Development, Environment and People \\ Volume 5, Issue 1, 2016 \\ URL: http://jedep.spiruharet.ro \\ e-mail: office jedep@spiruharet.ro
}

participants in the program. The coordination of the efforts directed towards achieving the social objectives of the program must be combined with the obtaining of social benefits by the participants in it.

Social programs acquire an active character as a result of the expanding of the members and the systematic unification of the participants in the program on the partnership principle, but also as a result of economic stimulation, activation of their social actions, i.e. the opportunities for a strategic choice of the participants in the program are targeted, but within the realized social program. In the development of social programs this means that each participant in it, on account of his/her participation, solves some kind of social task that is of present interest to him/her. The active model of the social program implies the development of conditions for obtaining benefits from the participation in the social program. In the active program targeted systems, the manageable subjects are placed in conditions and have increased active management powers. What is of importance here are the conditions and the opportunities for freedom of choice of one's own state, the possibility to express one's own interests and preferences, i.e. deliberately choosing one's state, but in the priority system of the executed social program. The active model of the social program reflects the network structure of social management in the program implementation, within which the participants in the target social program have a high degree of freedom of action, aim at a choice of such strategies, which appear to be optimal in terms of their target results, with the preset or predictable meanings of the social potential used.

The development of an active targeted social program presupposes four components of its activation mechanism (Fig. 2).

First, the participants in the program have a wide range of choices of action to implement the objectives of their interests. This means that, on account of his/her participation in the program, each participant is interested in solving some social task that is of importance for him/her.

Second, the presence of a body of the social program, with broad composition of managers, with broad involvement of the public. This body must not only study the social results of the program implementation, collect data, evaluate the stages of the program implementation as a whole, but also develop guidelines for the correction of the program elements.

The third is determined by the system for motivation of a broad composition of participants in the program. The development and implementation of a social program requires a special form of motivation for an actively liberated, proactive, scientific style of work, determining self-education, creativity and innovation development in any workplace.

The forth - the necessity for a constantly operating innovation centre for innovative improvement of the social program, for activation of the processes of its renovation. 


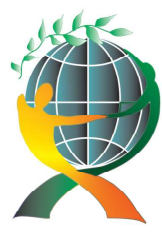

\author{
(online) $=$ ISSN $2285-3642$ \\ ISSN-L = $2285-3642$ \\ Journal of Economic Development, Environment and People \\ Volume 5, Issue 1, 2016
}

URL: $\underline{\text { http://jedep.spiruharet.ro }}$

e-mail: office jedep@spiruharet.ro

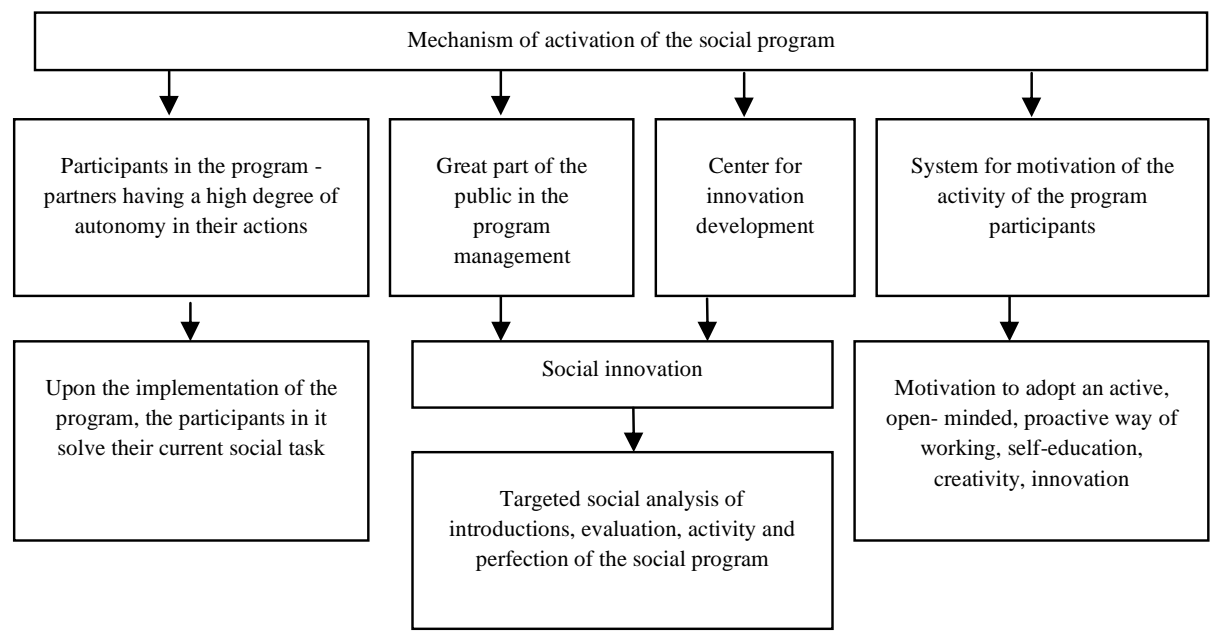

Fig. 2. Components of the mechanism of social program activation (Terziev \& Arabska, 2015c)

The highly qualified intellectual labour is a potential opportunity for self-improvement of the social program. The scientific innovative activity of the participants in the program - that is a self-increasing resource, having cultural and assessed value and determining the potential for active adaptation to the changing social conditions. "People performing mental labour possess their own means of production, i.e. the knowledge stored in their heads. This is an absolutely portable and unusually voluminous type of fixed capital. As the employees of mental labour are in control of their means of production, they are very mobile. Figuratively speaking, the employees of physical labour are more interested in the work than they are interested in them. But in most cases the relationship of the employees of intellectual labour with the organization providing work to them are characterized by the fact that they are equally interested in each other."

In this way, active social programs aim at solving social problems through the implementation of breakthrough, innovative social technologies, attraction of investments, optimization of social resource flows, and integration of the social systems. Social program development rejects the principle of an end of the carried out social events. Above all, every active social project is an innovation as its main objective is to be found in the development and the use of new ideas which may be new social technologies aimed at providing social services, ensuring the dynamic social development of the population.

Active social programs are created as a set of social projects on the basis of a unifying idea for social interaction guaranteeing the coordination of the interests of the population in the conditions of an unstable social environment of impact. An active social program is a system development. Taken separately, each component of an active social program is interconnected and interdependent on the other parts of the program. As a rule, the isolated realization of the individual elements of the social program, cut off from one another, creates conditions for a sharp reduction in the effectiveness of its implementation.

The unifying social idea of the active program is the optimal synthesis of thoughts, ideas and objectives of the program participants, among whom there are representatives of the public. Moreover, the 


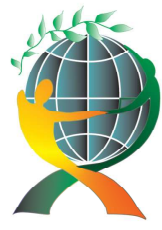

\author{
(online) $=$ ISSN $2285-3642$ \\ ISSN-L = 2285 - 3642 \\ Journal of Economic Development, Environment and People \\ Volume 5, Issue 1, 2016 \\ URL: http://jedep.spiruharet.ro \\ e-mail: office jedep@spiruharet.ro
}

participants in the social program are relatively independent, they act proceeding from their own interests - upon their participation in the social program, each one makes decisions in his/her own interest. The program is developed on the basis of the creation of a socially important unifying idea, so that the interests of the participants in the active social program can be consistent with the objective of the active program itself. The social program is developed based on the study of ideas and innovative thinking of the participants, based on a comprehensive analysis in the field of realization of the active social project, through the formation of a unifying idea and the design of schemes about the interests of the participants and the population. Then, taking as a starting point the obtained data, the structure of the active social program is formed, a network of organizations with the program participants is created around the representative of the unifying social idea, who enters into the role of a coordinator and supervisor of the program implementation.

Active social programs share a number of common characteristics: they are aimed at achieving specific objectives; incorporate the coordinated execution of interrelated actions; they have an action limited in time with a defined beginning and a specified period for drawing up of a new program or its completion; to a certain extent they are unique.

\title{
4. Conclusion
}

The result of active social programming allows the realization of complex programs with maximum efficiency in a rapidly changing social environment. Moreover, the unifying ideas ensure the involvement of relatively independently functioning social institutions by coordinating their needs and interests. The active approach primarily aims at obtaining effective development of the social object of the program by introducing disruptive technology innovation, attracting the public to the management, optimizing the resource flows, integrating the social systems of the participants in the program. The term "active programming" emphasizes on the continuous process of adaptation of the developed program to the conditions of the social environment in the system. Therefore, an active social program is open for system self-development. The success of its management implementation is largely determined by the factors of the interaction of the social program elements with its constantly changing impact environment. Unlike conventional social programs, the active form of social programming is a creative self-developing project with transformable final social goals, means and tasks of the process of social changes, with rejection of the rigid static schemes of the classical social programming. Active social programs are aimed at local social stabilization in unstable, dynamically changing conditions of the environment for social impact. Active programming is mainly oriented towards the effective development of social objects through development of innovations; optimization of financial, resource and innovation flows; integration of socioeconomic projects in the global economic relations.

The information obtained as a result of social research on the conditions for program implementation is the basis for the formation of any significant, systemically interrelated factors for social changes, reflecting the nature of the ongoing processes and phenomena. The participants in an active social program have and realize skills for an active creative conduct related not only to the development and organization of the social program implementation, but to the ability to accumulate and to reasonably apprehend different kind of innovations. The realization of the social program largely depends on the professionalism 


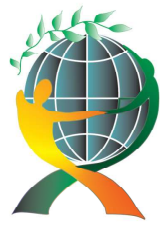

\author{
(online) $=$ ISSN $2285-3642$ \\ ISSN-L = $2285-3642$ \\ Journal of Economic Development, Environment and People \\ Volume 5, Issue 1, 2016 \\ URL: http://jedep.spiruharet.ro \\ e-mail: office jedep@spiruharet.ro
}

of its realization. In the modern conditions of professionalism, this is a major criterion for the qualities of the program.

\title{
5. References
}

[1] Stoyanov, E. (2015). Opportunities for Development of Effective Management in Social Programming. New Knowledge Journal of Science, Vo. 4, No3, pp. 21-25.

[2] Terziev, V. (2015a). Impact of Active Social Policies and Programs in the Period of Active Economic Transformations in Bulgaria: monograph / 1st edition. - Vienna: "East West" Association for Advances Studies and Higher Education $\mathrm{GmbH}$.

[3] Terziev, V. (2015b). Challenges before Social Programming in the Context of Social Activity Encouragement and Social Development Regulation through Active Policies. Ruse.

[4] Terziev, V. (2015c). Social Programming in the System of Sociological Categories Concerning Market Economy and Labour Market Development in Transition Economy. URL: http://cyberleninka.ru/article/n/social-programmingin-the-system-of-sociological-categories-concerning-market-economy-and-labor-market-development-intransition-economy (Accessed: 26.01.2016)

[5] Terziev, V., Arabska, E. (2015a). Assessment of the Effectiveness of Social Programming. Fifth International Scientific and Applicative Conference KNOWLEDGE - WHO AND WHAT, 21-25 May 2015, Bansko, Bulgaria, Journal of Process Management (JPMNT) - New Technologies, International, The International Scientific Conference "KNOWLEDGE - WHO AND WHAT" (held in Bansko, 21-25 May 2015), Special Edition, Volume 9, May 2015, pp. 119-131.

[6] Terziev, V., Arabska, E. (2015b). Social Policy and Social Programming: Key Implications Concerning Development of Active Labour Market Policies and Employment. Proceedings of 17th International Academic Conference, Vienna, June 21-24, 2015, IISES, pp. 499-513.

[7] Terziev, V., Arabska, E. (2015c). Theoretical and Methodological Basis of Social Programming and Social Activity. Collective Monograph. Socio-Economic and Law Basics of Economic Development, Ufa-Aeterna, pp. 3-183

[8] Terziev, V., Dimitrova, S. (2015). Social Programming in the Context of Stimulating Social Activity and Regulation of Social Development through Active Policies. „East West” Association for Advanced Studies and Higher Education, Vienna.

[9] Terziev, V., Dimitrova, S., Arabska, E. (2015a). Assessment of Active Social Policies' Impacts on Labour Market in a Period of Transformation Bulgarian Society. Procedia Economics and Finance 30 (2015), pp. 890-902.

[10] Terziev, V., Dimitrova, S., Arabska, E. (2015b). Ways of Effective Social Policy Implementation through Encouragement of Social Activity. International scientific conference "Education, science, economy and technology", University "Prof. D-r Asen Zlatarov" - Burgas, Journal Management and Education XI (9), pp. 34-39. 


\author{
(online) $=$ ISSN $2285-3642$ \\ ISSN-L = $2285-3642$ \\ Journal of Economic Development, Environment and People \\ Volume 5, Issue 1, 2016 \\ URL: http://jedep.spiruharet.ro \\ e-mail: office jedep@spiruharet.ro
}

[11] Terziev, V., Dimitrova, S., Arabska, E. (2015c). Social Activity of Human Resources - A Basis for Effective Social Policy. Fifth International Scientific and Applicative Conference KNOWLEDGE - WHO AND WHAT, 21-25 May 2015, Bansko, Bulgaria, Journal of Process Management (JPMNT) - New Technologies, International, The International Scientific Conference "KNOWLEDGE - WHO AND WHAT" (held in Bansko, 21-25 May 2015), Special Edition, Volume 9, May 2015, pp. 241-246.

[12] Terziev, V., Stoyanov, E., Arabska, E. (2015). The Active Social Program - An Innovative Model in Social Development. Youth Forums „Science, Technology, Innovations, Business” Proceedings, 2015, pp. 125-130. 